\title{
(75) 水素中の微量の一酸化炭素除去に關する一新方法
}

\author{
川北公·夫 一 柳 文二
}

\section{〔I〕緒言}

アンモニア合成工業が發展してより工業用水素の重要性は日每 に大きくなつて行く事は衆知の事實である。硬化油の製造, メタ ハールの合成, 不炭の液化等水素化を根元とする大工業が續々と 起つて來たのである。之等の工業は何れも觸媒を用ふるもので, その原料である水素を純粹に且つ廉價に得る事が重要な問題であ る。

純粹な水素は水の電解に依つて得られるが近來は水性ガスから 得る方か濂價につく䉆, 工業用水素源として石炭が探用せられる 樣になつた。後者の場合には水性ガス反應によつて一酸化炭素を 水素に遷移するのであるが，此際殘留する一酸化炭素の微量は仲 々除去し難い。アンモ二ア合成の觸媒に於ては特にこの微量の二 酸化炭素が毒として働くと考へられるので，之が除去には幾多の 方法が試みられてるる (J. Schmidt: Das Kohlenoxyd)。

本研究は特許第 122712 號の方法により還元鐵を觸媒として $350^{\circ} \sim 400^{\circ} \mathrm{C}$, 常厴に於て水素中の微量の一酸化炭素を除去しよう 之試みたものである。活性なる還元鐵は一酸化炭素を炭素々二酸 化炭素に接觸分解するのみならず二酸化炭素をも化學的に吸着す る。此の反應の物理化學的研究は既に「物理化學の進步」誌上に 於て發表した (川北会夫, 物理化學の進步 8,89, 昭和 $9 ; \mathbf{1 1}, 75$, 昭和 $12 ； 10,200$, 昭和 $11 ； 12,105$, 昭和 $13 ; 13,87$, 昭和 14 )。 今尼は此の反應を工業的に應用せんとする企ての第一步として流 動法によつて實驗を行つた。

流動法による實驗に於ては先づ一酸化炭素の微量分析が問題と なるのである。從來行はれた分析方法は本實驗に於ては满足する 樣な條件を具へてるない雼先づ一酸化炭素の微量分析を䇦備實驗 として行ひ，後之を用ひて一酸化炭素の除去率と流動速度との關 係及び能媒能力に關する實驗等を行つたので弦に之等を䌈めて報 告しよらと思ふっ。

\section{〔II〕一酸化炭素の微量分析に關する禅備實驗}

（1）從來の諸方法に就ての吟味

一酸化炭素の分析は多くの方法が考案されてるるが，之を大別 すると次の如くなる。

（i）一酸化炭素の還元性を利用する方法 a) 重金屬例へばパ ラデゥム等の盢類溶液より夫等金屬を析出せしめる方法，b) 五酸 化沃素より沃素を遊離せしめ之を沃素カリ溶夜で捕獲し，チオ硫 酸ナトリゥム溶液で滴定する方法。

(ii) 一酸化炭素と一モグロビンの結合を利用する方法 a）稀 溥血液に一酸化炭素を吸收せしめ, 之に硫酸ナトリウム或は硫酸 アンモニウム溶液を加へて一酸化炭素へモグロビンを分光器を用 ひて检出或は定量寸る方法，b) 稀溥血液に一酸化炭素を吸收せし

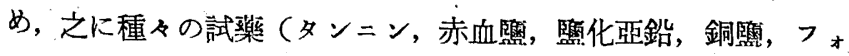
ルマリン等)を添加しその色相の變化によつて檢出する方法。

(iii）一酸化炭素を第一銅照溶液に吸收せしめる方法。

(iv) 一酸化炭素を酸化䜞にて二酸化炭素として之を定量する 方法 a) 酸化劑として五酸化沃素を用ひる方法， b) 觸媒 (Hopcalit，酸化銅）を用认酸素と共存せしめて酸化する方法。

（v）一酸化炭素を直接燃燒せしめて分析する方法。

（vi）一酸化炭素を觸媒上で水素と反應せしめてメタンとして 定量する方法。

以上の諸方法は主として室氣中の一酸化炭素を分析するのには 好都合であるが，本實驗の目的の如く水素中の微量一酸化炭素の 分析には必ずしも適當ではない。

上記のわのより敏感度か高く且つ本實驗に使用し得るすのを求 めてみると，(ii) a，及び b，の方法が一番適當してるると考へら れる。向 (i)b，の方法が水素认依つて影響を受けないならば沃素 の分析は銳敏で充分目的を達する事が出來ると考へられる。

以上の考察に基き先づ (i) b，の五酸化沃素を用ふる方法と (ii) のニモグロビンを用ふる方法とにつき䂆備實驗を行つた。

\section{（2）篟 備 實 驗}

(i) 五酸化沃素より沃素を遊雃せしめて之を沃素カリ溶液にて 捕喓して分析する方法 此の方法は

$$
\mathrm{I}_{2} \mathrm{O}_{5}+5 \mathrm{CO}=5 \mathrm{CO}_{2}+\mathrm{I}_{2}
$$

なる反應によつて生ずる沃素を定量する事によつて行ふのであ る。

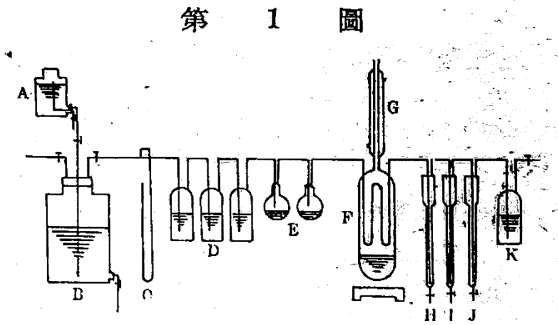

A： ガス置換用水溜， B： 方ス溜，

C: 水銀マノメーター,

D: $\mathrm{CO}_{2}$ 吸收用洗滌嚗 $\left(\mathrm{KOH}^{\prime}: 1\right)$

$\mathrm{E}$ : 乾燥用 5 酸化憐嚗,

F：5. 酸化沃素管定溫加熱器， G：冷却管，

$\mathrm{H}, \mathrm{I}, \mathrm{J}$ : 沃素吸收管 (沃化引溶液)，

$\mathrm{K}$ : 洗 滌㙾

裝置の大降は第 1 圖に示すが如くである。 操作は先づ全裝置內を水素で置換し次に F を加熱し後 $\mathrm{A}$ より B に水を注入し检體がスを B から徐々に全裝置を通過さ世る。 一定時間通過後再び全裝置を水素で置換し H に捕獲された沃素 の量を澱粉を指示藥としてチオ硫酸ナトリウムで滴定する。

(a)，五酸化沃素に對寸る水素の夕の作用 水素は市販の電解 水素を用ひ數四實驗を行つた。その結果は第 1 表の如くである。

表に見られる如く五酸化沃素は水素のみによつて相當還元され
五酸化沃素(Merk 製)をガラスの蛇 管につめて之を醋 酸了ミルの沸騰せ る蒸氣浴中に置き 之に水素と一酸化 炭素の混合ガスを 揆り五酸化沃素管 を出たガスを沃素 カリ溶液中に小さ い氣泡として通し て, 後之を $N / 1000$ チ才硫酸ナトリウ ムで滴定し遊離沃 素を分析した。

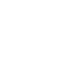

(n)


るものの如く, 其の還元される割合は水素の流動速度にも通過量 にも一定の關係がない樣に思はれる。

（b）五酸化沃素に對する水素, 一酸化炭素混合ガスの影響,

上述の如く水素自身五酸化沃素に對して可なり影響を及ぼす事 が判つたが，妶では一酸化炭素 $0.00465 \%$ 含有の水素に就て (a) と同樣測定を行つた。其結果は第 2 表に示すが如くである。

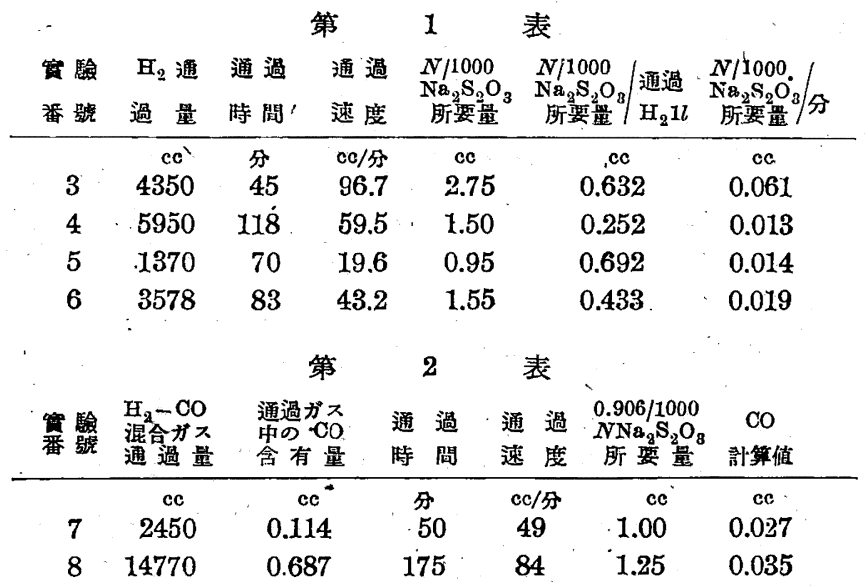

第 2 表に見る如くこの方法は水素中の微量の一酸化炭素を定量 するには適當でない。

(ii) 五酸化沃素によりー酸化崖掌を二酸化㞸素に酸化し之を岩 酸ソータ，フェノールフタレイン混合溶液に通じ其の脫色友應に依 つて分析する方法 稀薄岸酸ソーダ溶液に少量のフェノールフタ レイン溶液を加へたる混合溶液に二酸化炭素を通ずると炭酸り ダは酸性炭酸ソーダとなりフェノールフタレインが脫色される。 この反應の二酸化炭素の限界濃度は約 $0.008 \%$ で可なり銳敏であ る。此の反應が本實驗の目的に利用し得るか否かを實驗した。

ソーダ石灰で二酸化炭素を除去した空氣を始め吸收管に通し次 k微量の二酸化炭素と室氣との混合ガスを通じて觀察した。此の 脫色反應は銳敏ではあるが脫色の最終點を制定するのが困難であ つた。

(iii）五酸化沃素によりー酸化㞸素を二酸化㞸素に酸化し後之 を水酸化バリウム凸て分析する方法 检體ガスを五酸化沃素に通 じ先づ最初沃素カリ溶液に導き遊離沃素を捕獲し次に水酸化バリ ウえ $N / 50$ 溶液中に小さい氣泡として導き炭酸バリウムとして二 酸化炭素を捕獲し, 水酸化バリウムのアルカリ度の差異をN/1000 の苳酸で Bromthymol Blue-Phenol Red を指示藥として水素氣 流中で滴定を行つた。その結果は第 3 表の如くである。

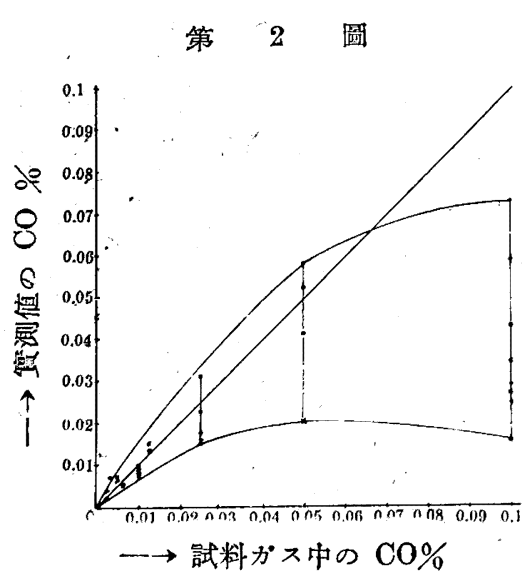

次に第 3 表の 結果 の一部を圖示すると 第 2 圖の如くなる。

圖に於て直線は實 際值を示すもので; 二つの曲線の間の部 分は實測值を表はす ものである。圖より

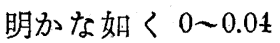
\%附近に於ては比較 的分析の正確度があ るが， $0.04 \%$ 以上に
第 3 表

\begin{tabular}{|c|c|c|c|c|c|}
\hline $\begin{array}{l}\text { 寞驗 } \\
\text { 番號 }\end{array}$ & 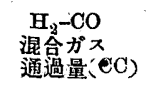 & $\begin{array}{l}\text { 通過ガ } \\
\text { 中田 } \\
\text { 含有 量 }\end{array}$ & 通過特閔 & 通過速庤 & $\mathrm{CO}$ 計算伎 \\
\hline 30 & 3000 & $0.15^{\mathrm{cc}}$ & 120分 & $25^{\mathrm{cc} / \text { 分 }}$ & $0.5^{\mathrm{cc}}$ \\
\hline 31 & 7300 & $0.00 "$ & $115 /$ & $63.4^{\prime \prime}$ & $0.32 \mathrm{cc}$ \\
\hline 35 & 6150 & 0 & $98 "$ & $61.7 \mathrm{II}$ & $0.18 \mathrm{cc}(?)$ \\
\hline 38 & 4600 & $0-11$ & $125 "$ & $36.8 "$ & $0.13 \mathrm{cc}(?)$ \\
\hline 39 & 7500 & $0.375^{\prime \prime}$ & $305 "$ & $24.5^{\prime \prime}$ & $0.52 \mathrm{cc}$ \\
\hline 131 & 1420 & $0.1 \%$ & 3 時間 & $473^{\mathrm{cc} / \text { 㭙 }^{\mathrm{s}}}$ & $0.034 \%$ \\
\hline 132 & 1150 & 0.11 & $5 "$ & $230 "$ & $0.027 "$ \\
\hline 138 & $1150^{\circ}$ & $0.1 /$ & $3 "$ & $383^{\prime \prime}$ & $0.02 .9 \mathrm{\prime \prime}$ \\
\hline 145 & 450 & $0.1 /$ & $5 "$ & $150 "$ & $0.025^{\prime \prime}$ \\
\hline 146 & 850 & $0.1 /$ & $5 "$ & $170^{\prime \prime}$ & $0.016^{\prime \prime}$ \\
\hline 147 & 1850 & $0.1 "$ & $5^{\prime \prime}$ & $370 "$ & $0.059 "$ \\
\hline 148 & 1400 & $0.1 "$ & $5^{\prime \prime}$ & $280^{\prime}$ & $0.073 "$ \\
\hline 149 & 2300 & $0.1 "$ & $5 "$ & $466 "$ & $0.043 "$ \\
\hline 133 & 850 & $005 \%$ & $3 "$ & $283 "$ & $0.002 "$ \\
\hline 139 & 1250 & $0.05^{\prime \prime}$ & $5 "$ & $250 "$ & $0.052 "$ \\
\hline 140 & 650 & $0.05 "$ & $5^{\prime \prime}$ & $130 "$ & $0.058^{\prime \prime}$ \\
\hline 150 & 2300 & $0.05 "$ & $5 "$ & $460 "$ & $0.041^{\prime \prime}$ \\
\hline 134 & 2250 & $0.025 "$ & $5^{\prime \prime}$ & $450 "$ & $0.016^{\prime \prime}$ \\
\hline 137 & 2000 & $0.025 \prime \prime$ & $5 "$ & $400 "$ & $0.015^{\prime \prime}$ \\
\hline 141 & 1350 & $0.025 "$ & $5 \prime \prime$ & $262^{\prime \prime}$ & $0.032 \%$ \\
\hline 142 & 1600 & 0.025 & $5^{\prime \prime}$ & $320 \%$ & $0.017 " \prime$ \\
\hline 152 & 2350 & $0.025 "$ & $5^{\prime \prime}$ & $470^{\prime \prime}$ & $0.031 "$ \\
\hline 154 & 2630 & $0.025 "$ & $5 "$ & $526 "$ & $0.022^{\prime \prime}$ \\
\hline 144 & 870 & $0.0125 "$ & $5 "$ & $174 "$ & $0.013 "$ \\
\hline 155 & 2200 & $0.0125 "$ & $5 \prime$ & $440 \%$ & $0.015^{\prime \prime}$ \\
\hline 89 & 1550 & $0.01 / 1$ & $5 \%$ & $310 \%$ & 0.6097 \\
\hline 90 & 4050 & $0.01 "$ & $5 "$ & $810 "$ & $0.0075^{\prime \prime}$ \\
\hline 91 & 2300 & $0.01 "$ & $5^{\prime \prime}$ & $460 "$ & $0.007 "$ \\
\hline 92 & 1550 & $0.01 /$ & $5 \%$ & $310 "$ & $0.0081^{\prime \prime}$ \\
\hline 93 & 2150 & $0.01 "$ & $5 "$ & $430 "$ & $0.0088^{\prime \prime}$ \\
\hline 156 & 2200 & $0.0062 "$ & $5 \%$ & $440 "$ & $0.005^{\prime \prime}$ \\
\hline 94 & 2200 & $0.005^{\prime \prime}$ & $5 \prime$ & $440 "$ & $0.007 . "$ \\
\hline 95 & 1050 & $0.005^{\prime \prime}$ & $5 "$ & $210^{\prime \prime}$ & $0.0064 "$ \\
\hline 158 & 2300 & $0.0031 "$ & $5 "$ & $460 "$ & $0.007^{\prime \prime}$ \\
\hline 96 & 1400 & $0.0025 "$ & $5^{\prime \prime}$ & $270^{\prime \prime}$ & 0.0039 " \\
\hline 98 & 2100 & $0.0025 "$ & $5 "$ & $420 "$ & $0.0021 "$ \\
\hline 99 & 2250 & $0: 00125^{\prime \prime}$ & $5 "$ & $450 "$ & $0.0069^{\prime \prime}$ \\
\hline 100 & 2350 & $0.00125 "$ & $5 "$ & $470 "$ & $0.0031^{\prime \prime}$ \\
\hline 101 & 2050 & $0.00125 "$ & $5^{\prime \prime}$ & $410 "$ & $0.0084 \prime \prime$ \\
\hline 102 & 3200 & $0.00125 "$ & $5 \prime \prime$ & $640 "$ & $0.0024^{\prime \prime}$ \\
\hline 104 & 2400 & $0.00125^{\prime \prime}$ & $5 "$ & $480 "$ & $0.0035 \prime \prime$ \\
\hline 105 & 2900 & 0 & $5^{\prime \prime}$ & $580 "$ & $0.0044 "$ (?) \\
\hline 106 & 3200 & 0 & $5 "$ & $640 "$ & $0.0025 "$ "? \\
\hline 136 & 4.150 & .11 & $3 "$ & $1380 "$ & $0.0048 /(?)$ \\
\hline
\end{tabular}

なると一酸化炭素の實測值が實際值よりも小に出て來る倾向が ある。

（iv）血液の呈色反礁を用予る方法 五酸化沃素を用ふっる一酸 化炭素の分析は充分滿足すべき結果が得られなかつた。故に血夜 の呈色反應を用ふる方法 (J. Echmidt, “Das Koh'enoxyd” S. 189１90）につき調査した。先づ $20 \%$ 血液 20:c に少量の一酸 化炭素を通じ之を試料とする。

1. タンニン法 $5 \mathrm{cc}$ の試料に $1 \%$ タンニン溶夜 $15 \mathrm{cc}$ を加へ 長時間放置す。一酸化炭素を吸收せるものは赤褐色の沈搌を生じ 一酸化炭素を吸收せざるものは最初は稍赤色なるも，時間の經過 と共にチョコレート色の沈澱を生ずる。

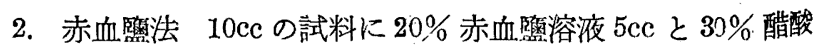
1cc を加へる。一酸化炭素を吸收せるものは直ちに赤色の沈澱を， 
生ずる。一酸化炭素を吸收せざるすのは灰褐色の沈源を生ずる。

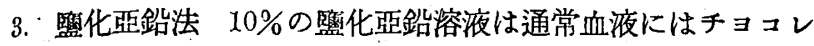
一ト褐色を與へるがー酸化炭素を含むもものは透明な櫻色を與へ る。

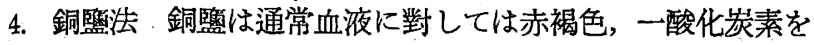
吸收せるものに對しては煉瓦色を與へる。

5. 醋酸鉛法 銅監法に同じ。

6. フォルマリン法 $10 \%$ フォルマリンは通常血液に對しては くすんだ褐色，一酸化炭素を吸收せるものに對しては赤色を與へ る。

7. ナトロン法 比重 1.34 の炭酸ソーダは通常血液に對して は帶綠褐色，一酸化炭素を吸收せるものに對しては灰白色の溷濁 を與へ,之を放置すれぼ淡紅色の絮狀物となり液の表面に集まる。

8. 硫化水素法 硫化水素の飽和水溶液は通常血液に對しては 活喑淥色，一酸化炭素を吸收せるものに對しては類紫色を帶びる 淡紅色を與へる。

9. 硫化アンモニア法 黃色硫化アンモニウムの少量を加へて 輕く振盪したる後 $30 \%$ 醋酸を加へると, 通常血液にありては活

綠色，一酸化炭素を吸收せるものにありては美麗なる艎微紅色を 呈する。

\section{第 3 圖}

A：血液及洗滌水入口,

B：ガラス破片,

C: 球狀ガス吸收部,

D：血液溜,

$\mathrm{E}$ ：試料取出口,

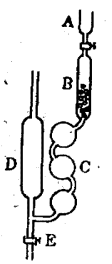

上記の諸方法に就て微量の一酸化炭素 を含を水素を检體とし行つた。此際水素 單獨にては血液の呈色反應に對して何ら 影響せぬ事を確めた。血液は新鮮なる牛 血に硼砂の飽和溶液を同量加一或は少量 のアルコール，又は之とくえん酸ソーダ ( $3 \%$ 溶液), 硫酸マグネシウム ( $25 \%$ 溶液) を办へたるるのを使用した。

上記の血液を $5 \mathrm{cc}$ とり第 3 圖に示す が如き吸收管に入れ，之に检體ガスを通 じ, 後血液を取出し $10 \mathrm{cc}$ の蒸溜水で洗 ひ洗淮水と共に之を試料とした。佮之と 比較對照する篬檢體 ガスを通ぜざる上記血液 5cc を 10ce の蒸 溜水で薄めて比較試驗を行つた。其の結果は第 4 表の如くであ る。

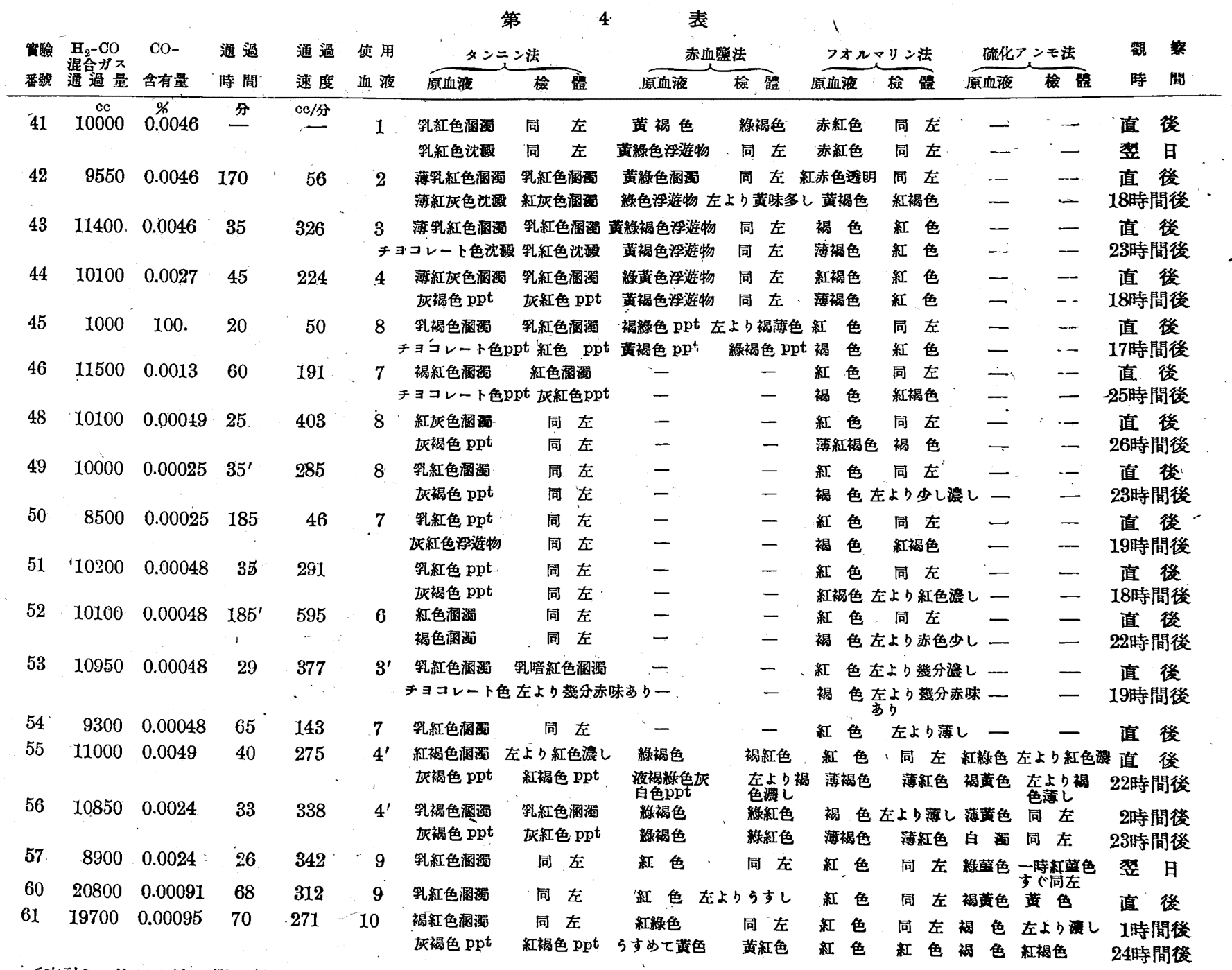

〔表註〕使用血液の欄に於ける番號は血液の處理方法の異なるもので 1 は嗍砂の能和溶液を同量加一たもの，5は之を滤過せる

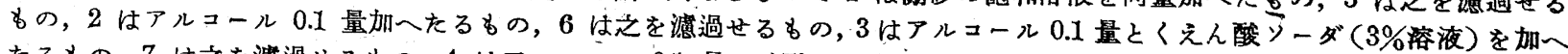

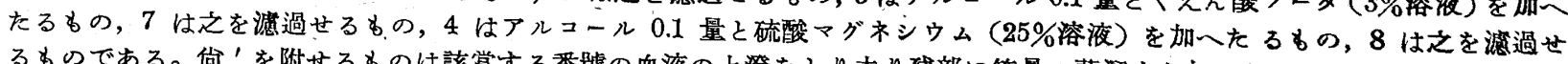

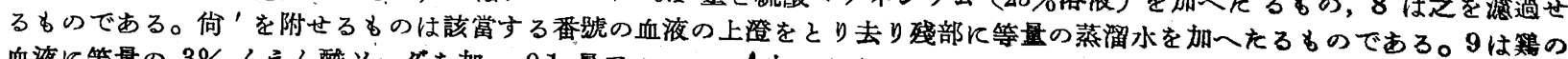

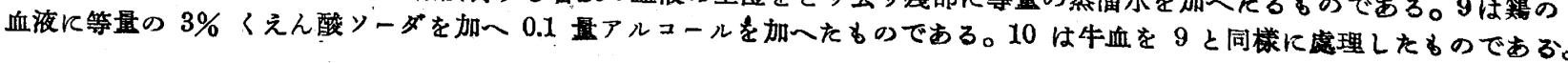


第 5 表の結果をみると $207 /$ 時の流動速度で檢體を血液に这る 時 $0.001 \%$ 一酸化炭素を含むりのはタンニン法で確實に检出し得 る事が判る。尚タンニン法に於ける一酸化炭素の检出限界濃度は 大體 $0.0005 \%$ 附近である，事が制る。タンニン法以外は銳敏度も大 ならず，色調の變化も一定してるないようである。タンニン法に 於ては比較的反應が紱慢である䉆, 一酸化炭素の含有量少なきす のに於ては血液の呈色反應は 24 時間後に於て初めて明確に出て 來る。血液の處理方法によつても一酸化炭素の檢出感度は可なり 異つて來る。

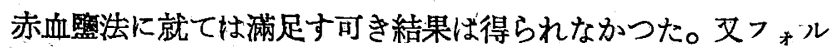

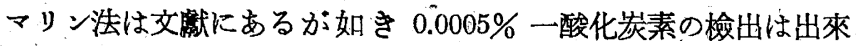
なかつた。硫化水素法に就ては $0.001 \%$ 一酸化炭素は檢出可能で あるが，此際硫化水素夜は充分硫化水素で飽和したものでないと 著明に出て來ない。硫化アンモ二ア法は $0.005 \%$ 一酸化炭素でも 明確な結果は得られなかつた。鴙血は牛血に比較して一酸化炭素 の检出には保存の點及び敏感度の點に於て好結果を得られなかつ た。

以上の結果より牛血を吸收劑として水素，一酸化炭素混合ガス を $20 l /$ 時の速度で吸收管內に䢪ると $0.001 \%$ の一酸化炭素は正確 に检出出來る事が制る。故に先づ血液法を用ひて水素中の徽量の 一酸化炭素除去に關する害驗を行つたのである。

\section{（III］觸媒能力に關する實驗}

一酸化炭素が $300^{\circ} \sim 400^{\circ} \mathrm{C}$ 附近に於て還元鐵と接觸する時

(i) $2(\mathrm{CO})_{\mathrm{Ads}}=\mathrm{C}+\left(\mathrm{CO}_{2}\right)_{\mathrm{Ads}}$

(ii) $\mathrm{Fe}+\left(\mathrm{CO}_{2}\right)_{\mathrm{Ads} .}=\mathrm{Fe}_{x} \mathrm{O}_{y}+(\mathrm{CO})_{\mathrm{Ads}}$

ななー種の不均一連鑟反應が起り一酸化炭素及び生成された二酸 化炭素が除去される事は著者の1人川北が既に見出した所であ る。

而して水素が一酸化炭素と共存する場合には（ii）の反應によ つて生成された鐵の酸化物が水素により還元されるので，水素て 共存する場合に於ては還元鐵の活性度は長生命を維持するすのと 考へられる。固相に於ては炭素を析出し，一方酸化鐵の水素によ る還元の爲水を生成する。此際他の炭化水素の生成は全く無い事

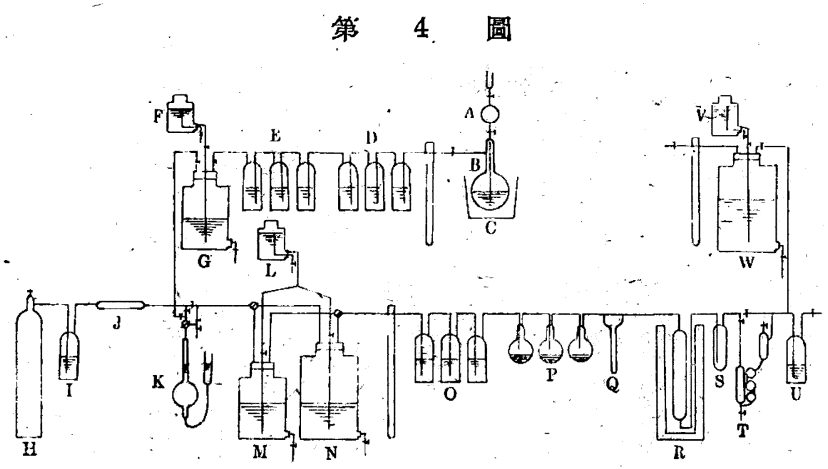

A: 嶬酸溜, B：CO 登生器 (濃硫酸), C: 加熱用油槽, D: $\mathrm{CO}_{2}$ 吸收用沙滌嚗 $\left(\mathrm{KOH} \mathrm{55 \% ),} \mathrm{E:} \mathrm{O}_{2}\right.$ 吸收用沙㹋 坛 $(55 \% \mathrm{KOH}+3.4 \%$ py ro; al'ol)， $\mathrm{F}$ ：ガ ス置換用水溜， $\mathrm{G}$ : CO ガス溜, H：水素ボンべ, I : 洗滌嚗 (濃硫酸), $\mathrm{J}: \mathrm{O}_{2}$ 除去用白金アスベネ卜， $\mathrm{K}: \mathrm{CO}$ 容量湘定装置, I: ガス置換用水溜， $\mathrm{M}, \mathrm{N}$ : $\mathrm{H}_{2}$ ガ ス溜， $\mathrm{O}$ : 乾燥用洗涤

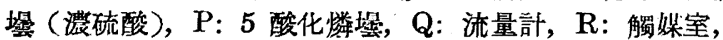
$\mathrm{S}$ : トラップ, T: CO 檢出用血液管, U: 洗滌躴, $\mathrm{V}$ : カ 不置换用水溜，W：廢ガス溜。
を確めた。

本實驗に於ては $3 \%$ 一酸化炭素含有の水素ガスを用てて其の除 去能力を調査した。實驗操置は第 4 圖に示す如くである。

份觸媒窒の詳細は第 5 圖の如きものである。
第 5 圆

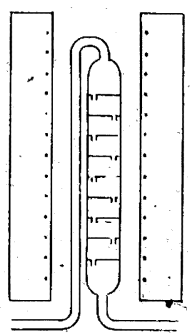

一酸化炭素は $90^{\circ} \sim 120^{\circ} \mathrm{C}$ の濃硫酸に蛈酸。 を滴下して發せしめ, 之を第 4 圖に於けるD， E の苛性カリ及びピロガロールで洗淮し， Gのガス溜に貯藏する。而して $\mathrm{K}$ なるビ。 レットにて所要量の一酸化炭素を取出し, 之 を M, N なる混合ガス溜に揆る。

水素ガスは市販電解水素のボンべより加㷫 白金アスベスト上を通じて精製した。

一酸化炭素の分析は第 3 圖に示すが如き吸 收管を用ひ，一定時間每に血液法によつて調査した。其の敏感度 は $107 / \mathrm{hr}$ の流速で檢體を揆つた時 $0.001 \%$ ０.0005\%一酸化炭素 が檢出できる。

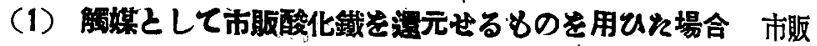
酸化鐵 $4 \mathrm{~g}$ を $350^{\circ} \sim 370^{\circ} \mathrm{C}$ にて約 24 時間水素を每時約 $1 l$ の速 度にて通じて還元したものを觸媒とした。實驗條件及結果を緾め て表示する之第 5 表の如くになる。その分析結果は第 6 表に示し てある。

\begin{tabular}{|c|c|c|c|c|c|c|}
\hline 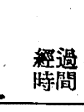 & 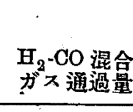 & $\begin{array}{c}\text { 第 } \\
\text { 通過ガス中 } \\
\text { の00含有量 }\end{array}$ & $\begin{array}{c}5 \\
\text { 同左 }\end{array}$ & $\begin{array}{c}\text { 表 } \\
\text { 通過速度 }\end{array}$ & 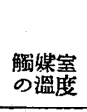 & 分析番啒 \\
\hline $25^{37}$ & l & ec & $\%$ & /㬶 & $\begin{array}{l}\text { oc } \\
354\end{array}$ & 分析 1 開始 \\
\hline 53 & 20 & 600 & 3 & 22.7 & 352 & \\
\hline 85 & 30 & 900 & " & 18.8 & 357 & 分析 1 終了 \\
\hline 138 & .50 & 1500 & " & 22.7 & 362 & \\
\hline 195 & 60 & 1800 & " & 10.5 & 362 & 分析 2 開始 \\
\hline 210 & 63 & 1890 & " & 12.0 & 362 & 分析 2 䅂了 \\
\hline
\end{tabular}

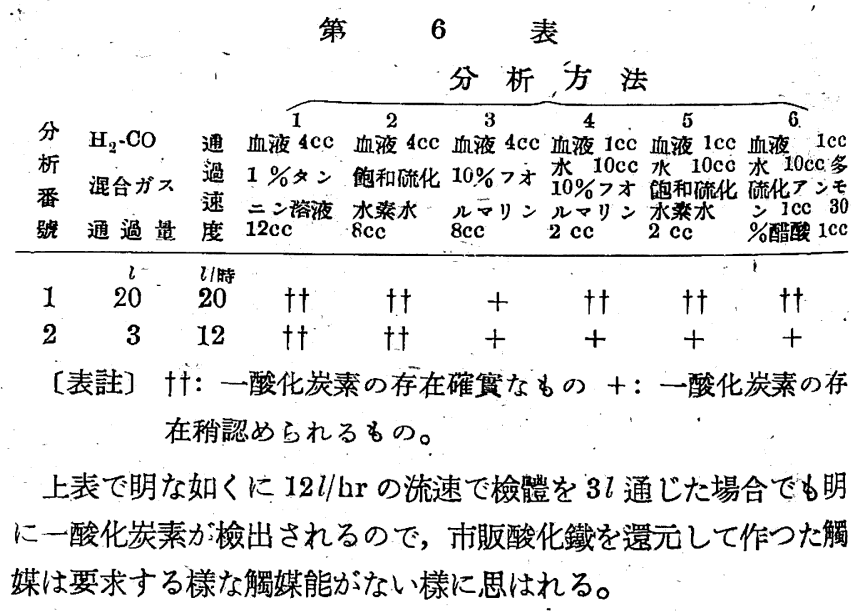

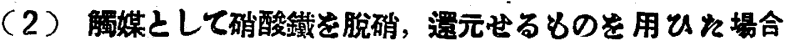

Kahlbaum 製硝酸鐵を $300^{\circ} \sim 400^{\circ} \mathrm{C}$ 、汒於て脫硝し(二トロ醋 酸溶夜にて硝酸根の無い事を確めた), 酸化鐵となし, この $8 \mathrm{~g}$ を とり $360^{\circ} \sim 370^{\circ} \mathrm{C}$ に於て約 24 時間水素を每時約 $1 l$ の速度にて 通じ還元して觸媒とした。實驗條件及び結果を纆めて表示すると 第 7 表の如くなる。

第 7 表の結果を考察してみるに觸媒室の溫度 $360^{\circ} \mathrm{C}$ 附近に於 ては流動速度 $87 / \mathrm{hr}, 4 l / \mathrm{hr}$ に於ても血液反應のタンニン法に於て。 稍一酸化炭素が檢出される。然しながら溫度を $400^{\circ} \mathrm{C}$ 附近に上 
第 表

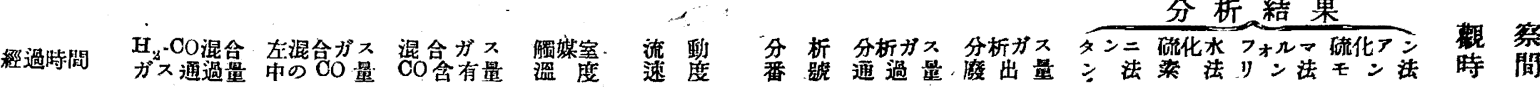

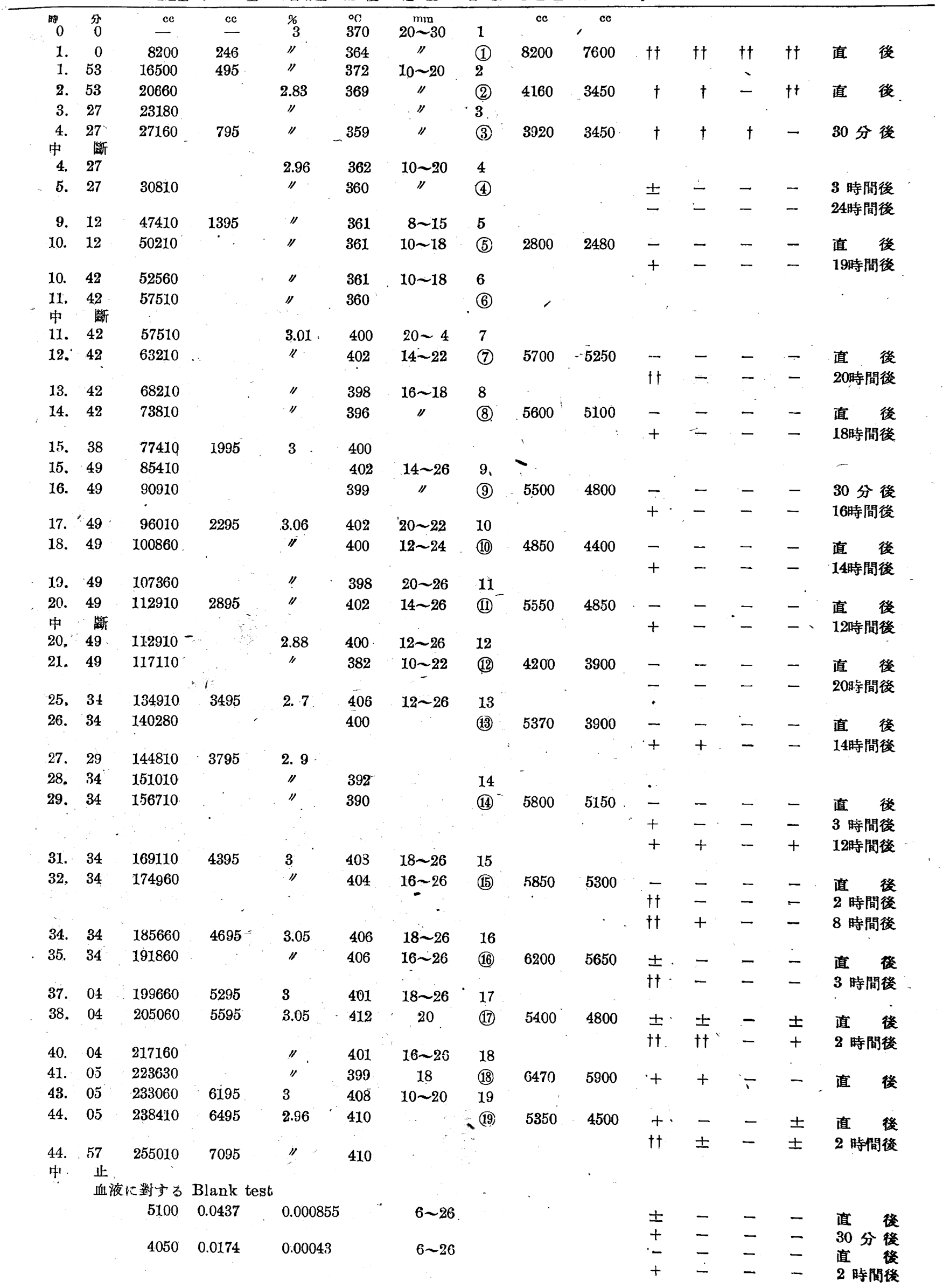




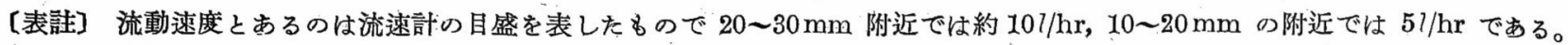
分析番號とあるのは施行分析の回數で，圆のない數の時分析を始め，同數の国のある時に終つた事を示す。分析結果に於

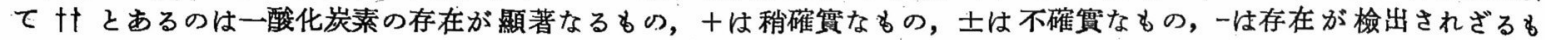
のである。

昇せしむると 5〜6l/hr の流動速度では一酸化炭素か殆んど检出 されない場合が多く,タンニン法で 10 時間後に呈色反應が表は れるから，觸媒室を出たガス中には $0.0005 \%$ 附近或は夫以下の 一酸化炭素しか含まれて居らない事が制る。尙この狀態で實驗を 繼續して行くと分析番號 15 に於てタンニン法で 2 時間後に稍一 酸化炭素が检出される樣になつた。この分析番號 15 は反應溫度 $400^{\circ} \mathrm{C}$ 它操作始めてから 36 時間, 混合ガス通過量は約 191 , 一 酸化炭素の量約 $5.7 l$ で, この觸媒を用ひ始めてから約 45 時間， 混合ガス通過量約 2557 , 一酸化炭素通過量約 $7 l$ である。更に 12時間實驗を續行したが，夫以後は大した變化は認めなかつた。 郎ちこの實驗の範園に於ては，觸媒室の溫度 $400^{\circ} \mathrm{C}$ で $3 \%$ の一 酸化炭素を含を水素ガスを 4 ～ $5 / / \mathrm{hr}$ の流動速度で通寸時には一酸 化炭素は少くとも $0.001 ０ .0005 \%$ 程度或は夫以下除去する 事が出來ると考へられる。

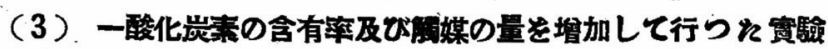
Kahlbaum 製硝酸鐵を $300^{\circ} \sim 400^{\circ} \mathrm{C}$ に於て脫硝して酸化鐵とな し, 之を $16 \mathrm{~g}$ 探り $363^{\circ} \mathrm{C}$ にて 24 時間水素を每時約 $1 l$ の速度 で通じて還元し觸媒とした。一酸化炭素 $5 \%$ 含有の水素ガスを觸 媒空に通じて，出たガスを血夜に通じて一酸化炭素を检出した。 第 8 表に實驗條件交結果を示した。血液呈色反應は最も銳敏なる タンニン法のみを記載した。

\begin{tabular}{|c|c|c|c|c|c|}
\hline 惯驗番啒 & 反鹤明 & & 反磼澄度 & 混合ガス通過速度 & 分析結果 \\
\hline 1 & $\begin{array}{l}10 . \\
10.0\end{array}$ & 00 & $363 \sim 365^{\circ 0}$ & $\stackrel{1}{1}$ & - \\
\hline 2 & 10. & 00 & $362 \sim 365$ & 1 & - \\
\hline '3 & 10. & 00 & $362 \sim 365$ & - 1 & - \\
\hline$\cdot 4$ & 7. & 00 & 362 364 & 1 & - \\
\hline 5 & 5. & 00 & $362 \sim 365$ & 2 & - \\
\hline 6 & 3. & 30 & $362 \sim 364$ & 3 & - \\
\hline 7 & 2. & 10 & $362 \sim 365$ & 5 & \pm \\
\hline 8 & 2. & 15 & $362 \sim 366$ & 5 & \pm \\
\hline 9 & 1. & 00 & 363 & 10 & + \\
\hline
\end{tabular}

上記の結果から $107 / \mathrm{hr}$ 以́下の流動速度に於ては一酸化炭素は 殆んど检出し得ない事が分る。郎ち觸媒の量を增加する事によつ て著しく除去能力か潪大寸ると考へられる。

\section{〔IV〕血液を用ひる分光分析}

以上は血液法の試薬による呈色反應を觀察する事によつて觸媒 の一酸化炭素に對する除去能率を調査したが，次に分光器を用ひ て夫等の吸收帶を調查した結果を述べる。

血色素の吸收帶ばオキシへモグロビン及び一酸化炭素へモグロ ビンの何れに於ても $\alpha$ 帶及び $\beta$ 帶の2つよりなつてるる事は從 來の研究より明である (Hariridge, Hoppe-Seylers, Z. physiol. Chem., 1912, 44, 1; 1920, 53，77; 1921, 54, 42 其他)，オキジ へモグロビン及び一酸化炭素へモグロビンに就て $\alpha$ 及び $\beta$ 帶を 比較すると第 9 表の如くである (Schmidt, “Das Kohlenoxyd” ร. 200 (1935))。

第 9 表より明な如く一酸化炭素を吸收せるへモグロビンは $\alpha$

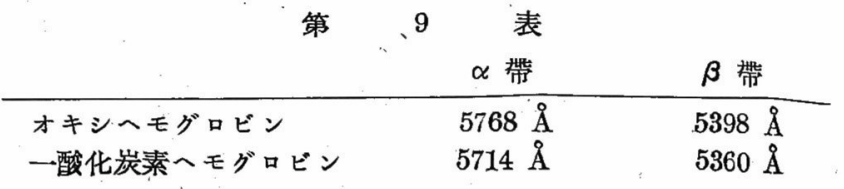

改び $\boldsymbol{\beta}$ 帶は共に波長の短い方に “ずれ”を生ずる。勿論一酸化 炭素の吸收の程度によつて其の示す吸收帶に多少の變化はあるか： (Balthiazard, Bull. Soc. Chim. Biol., 1924, 6, 817), 其の $\propto$ 帶 はオキシへモグロビンの $\alpha$ 帶 5768 より波長の短かい側に“ず れ”を生ずるのが原則である。

次に著者等の實驗結果に就て述べよう。Kahlbaum 製硝酸鐵 を $300 \sim 400^{\circ} \mathrm{C}$ 认於て脫硝して酸化鐵となし，之を $16 \mathrm{~g}$ と $263^{\circ} \mathrm{C}$ に於て 24 時間水素を每時約 $1 l$ の速度にて通じて還元し觸媒と した。 $5 \%$ 一酸化炭素を含む水素ガスを流動速度約 $37 / \mathrm{hr}$ 亿て觸媒 上を約 10 時間通過せしめ，觸媒公より出た水素ガスを同時間价 け血液吸收管に通じ，後この血液を稀釋して分光器にて調查し た。光源は $200 \mathrm{~W}$ 電球を用ひ, 可檢血液はベイリー管に大れ適

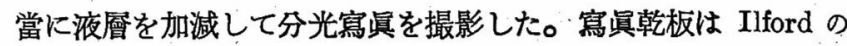
soft grad 4400 を使用した。その結果は第 6 圖の如くである。
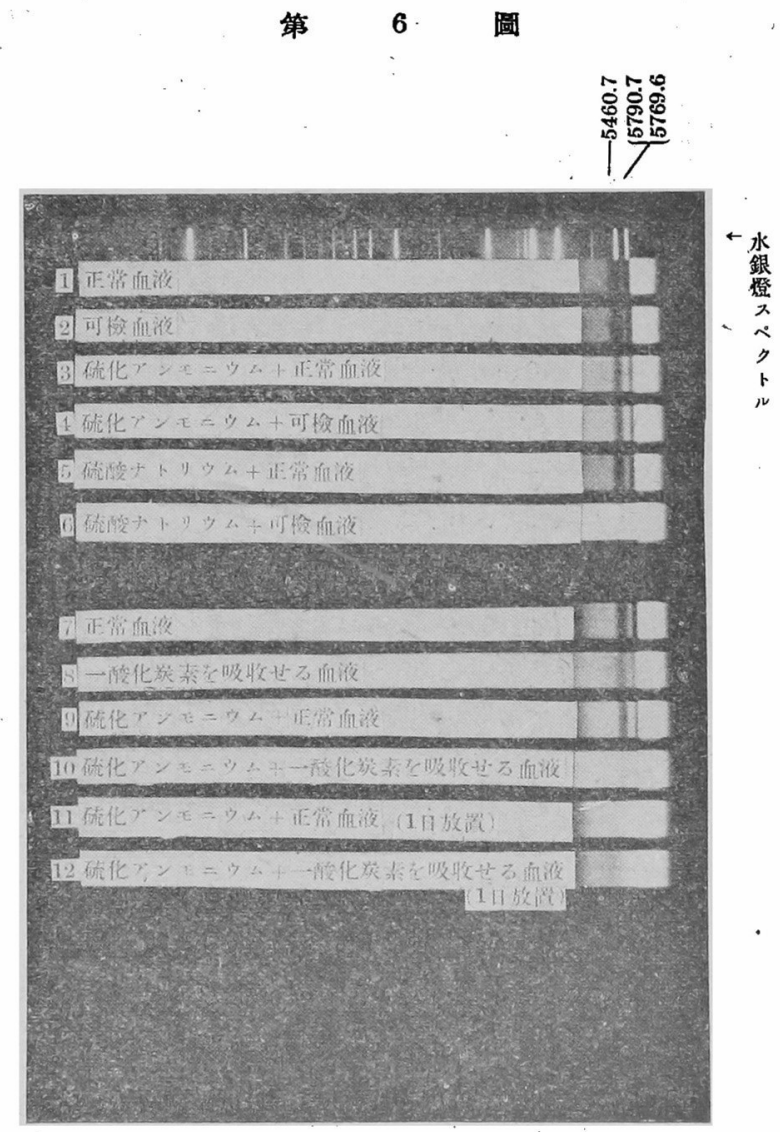

第 6 圖上り可检血液は認められるが如き吸收帶の變化を呈して るない事が制る。郎ち可检血液の $\alpha$ 及び $\beta$ 帶は正常血液に比較 して短波長側飞“ずれ”を生じてるない。佮硫化アンモニウム を加へたる場合には加へざる場合に比較して吸收帶が著明に現は れ，圖中 3 皮び 4 に於て觀られるが如く可检血液も一酸化炭素を 
含ま正常血液も全く同樣なる $\alpha$ 帶及び $\beta$ 帶を示してるる事が 判る。郎ち $5 \%$ 一酸化炭素を含む水素を $37 / \mathrm{hr}$ にて觸媒上に通ず る時は分光分析伦於ては一酸化炭素が認められないのである。 一方一酸化炭素を直接血液作用せしめて其の吸收帶を調查ず ると圖中８に觀られるが如く明かに短波長側に $\alpha$ 及び $\beta$ 帶は “ずれ”を生じてるる事が制る。

可檢血液, 一酸化炭素を吸收せしめた血液及び正常血液に就て 之等の $\alpha$ 帶及び $\beta$ 帶を緾めて 比較すると第 7 圆の如くである。

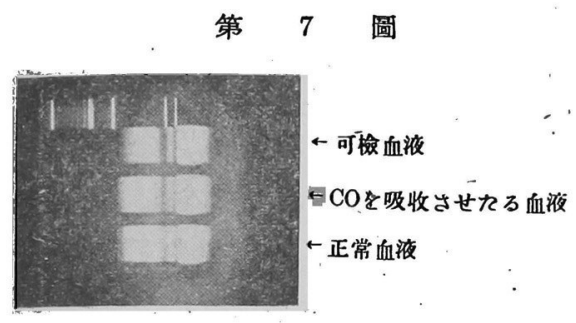

第 7 圖に於て 第 6 圖と同樣 可检血液は正常 血液と同樣なる $\alpha$ 及多 $\beta$ 帶を 示してみる事か; 制る。

\section{[v]結論}

以上述べた事を要約すると，水素と共存する一酸化炭素の微量 分析は,以上述ぺた方法では $0.000 .5 \sim 1 \%$ の間を正確に定量する事 は困難であつた。五酸化沃素を用ひて一酸化炭素を二酸化炭素と して定量する場合に於ても一酸化炭素 $0.04 \%$ 以上になると實测 值が不正確になる。茲に於て止むを得ず血液法による定性分析を 試みたが此の場合はタンニン法によつて 0.0005〜0.001\% 附近の 一酸化炭素は檢出し得る事が認められた。血液法を用ひて 3 〜 $5 \%$
の一酸化炭素を含有する水素より一酸化炭素を除去する還元鐵觸 媒の能力に關する實驗を行つた所, 數 $\mathrm{g}$ の觸媒に於ては, $3 \sim 5 l / \mathrm{hr}$ の流動速度に於て $0.0005 \sim 0.001 \%$ 附近或は其以下に一酸化炭素 が除去される事が認められた。

\section{[VI] 總括}

（1）水素中の一酸化炭素の微量分析につき種々吟味を行ひ, 敏感度の高きものにつき二，三の预備害驗を行つた。

(2) 一酸化炭素の微量を檢出する目的で血液の呈色反應を利 用する種々の方法を試みて，タンニン法が最も銳敏にして一酸化 炭素の 0.0005 ～ $0.001 \%$ 附近をよく检出の得る事を認めた。

（3）還元鐵を觸媒として水素中の微量一酸化炭素の除去に關 する實驗を行ひ血液法によつてその能力を检定した。 $4 \mathrm{~g}$ の市販 酸化鐵を還元せる触媒认於ては流動速度 $12 i / \mathrm{hr}$, 反應溫度 $360^{\circ} \mathrm{C}$ では除去能力が少ない事を認めた。碙酸鐵を脫硝して作つた酸化 鐵 $8 \mathrm{~g}$ を還元して作つた觸媒は $360^{\circ} \mathrm{C}$ 流動速度 $47 / \mathrm{hr}$ では 0.001 \%附近末で除去出來, 倘 $400^{\circ} \mathrm{C}$ に反應溫度を上げた場合タン二 ン法でも检出されない程除去出來る事が認められた。16g の酸化 鐵を還元せる觸媒は反應溫度 $360^{\circ} \mathrm{C}$ 附近に於ても流動速度 $57 / \mathrm{hr}$ にてタンニン法で檢出されない程度に一酸化炭素を除去し得る事 を認めた。

（4）血液による分光分析により更に上記の事實を確かめた。

終りに臨み，本研究を篇すに當り，終始御想篤なる御指導を賜 はり去る堀場先生に厚き感謝の意を表す。

\section{(76 77) 炭化石灰を還元劑とする金屬マグネシウム 製造法の研究 (第 4 5 報)}

松浦梁, 作

\section{（第 4 報）. $\mathrm{MgCl}_{2}+\mathrm{CaC}_{2}=\mathbf{M g}+\mathrm{CaCl}_{2}+\mathbf{2 C}$ の反應條件}

實驗に用ひた原料の分析結果を第 1 表に示す。炭化石灰は第 2 報（本誌，昭和 $13 ， 42 ， 590$ ）第 1 表試料番號 B と同一品で ある。無水監化マグネシウムは局法含水監化マグネシウムに $\mathrm{NH}_{4} \mathrm{Cl}$ を加へて熔融脫水したものであるが, 若干の $\mathrm{NH}_{4} \mathrm{Cl}$ 殘留寸ると共に一部は解離して $\mathrm{MgO}$ を含有してるる。

第 1 表 原料分析表

\begin{tabular}{|c|c|c|c|c|}
\hline \multicolumn{2}{|c|}{ 岑化石灰 B } & \multicolumn{2}{|c|}{ 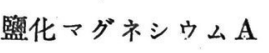 } & \multirow{2}{*}{ 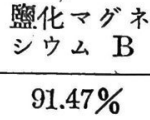 } \\
\hline $\mathrm{CaC}_{2}$ & $85.26 \%$ & $\mathrm{MgCl}_{2}$ & $65.04 \%$ & \\
\hline $\mathrm{CaO}$ & $1.65 "$ & $\mathrm{MgO}$ & $28.29 "$ & $7.76 "$ \\
\hline $\mathrm{M}_{g} \mathrm{O}$ & - & $\mathrm{NH}_{4} \mathrm{Cl}$ & $6.50 "$ & $0.92^{\prime \prime}$ \\
\hline $\mathrm{SiO}_{2}$ & $7.44 "$ & & & \\
\hline \multicolumn{5}{|c|}{$\mathrm{Fe}_{2} \mathrm{O}_{3}+\mathrm{Al}_{2} \mathrm{O}_{3} 5.39^{\prime \prime}$} \\
\hline C & $0.26^{\prime \prime}$ & & & . \\
\hline
\end{tabular}

之等粉末試料を町藏脀より取出し，手早く科量及び混合し，第 2 報と同一の實驗裝置及び方法により, 反應溫度及び減壓度を種
々變へて,之等が $\mathrm{Mg}$ 收率に及ぽす影響を見だ。每實驗の $\mathrm{MgCl}_{2}$ 便用量は第 2 表に示す如く一定しないか⿱，第 2 報 IIIに記す如く 此程度の原料變化は $\mathrm{Mg}$ 收率に影響する恐れはない。

實驗結果を第 2 表及び第 1 圖曲線 I-II'-II に示す。 $\mathbf{M g C l}_{2}$ は減型度 $1 \mathrm{mmHg}$ の時約 $500^{\circ} \mathrm{C}$ に於て反應を開始し, $\mathrm{Mg}$ 收率 (監化マグネシウム中の $\mathrm{MgCl}_{2}$ に對して示す。以下同樣)は反應 溫度の上昇に從ひ增加するが， $700^{\circ} \mathrm{C}$ を超えると却つて收率を減 少し, $1000^{\circ} \mathrm{C}$ 附近以上より再び之を增加する。700－1000 $\mathrm{C}$ で反 應溫度が高い程收率の低下を來すのは, $\mathrm{MgCl}_{2}$ が熔融し(熔融點 $\left.706^{\circ} \mathrm{C}\right)$, 減壓下で熔體の一部が蒸發し, $\mathrm{CaC}_{2}$ との還元反應に與 る $\mathrm{MgCl}_{2}$ の量を減ずる雹である。又 $1000^{\circ} \mathrm{C}$ 以上で再び收率を 增加するのは, 此溫度で $\mathrm{MgCl}_{2}$ の蒸發損失を益々增加するに俰 らず，原料中に含有する $\mathrm{MgO}$ が反應に與り(第 2 報照), 結 局 $\mathrm{MgCl}_{2}$ 及び $\mathrm{MgO}$ の兩者が同時に還元せられて, $\mathrm{MgCl}_{2}$ 單 獨の場合より $\mathrm{Mg}$ 生成量を增し, $\mathrm{MaCl}_{2}$ に對する見脚の收率を 增加するからである。故に曲線 I-II'-II の中 I-II' 部は $\mathrm{MgCl}_{2}$ 單獨の反應に相當し, II'-II 部は $\mathrm{MgCl}_{2}+\mathrm{Mg} \mathrm{O}$ の反應 に相當する。而して II'-II 部は原料中の $\mathrm{MgO}$ 含有量により 自ら變化があり, $\mathrm{MgO}$ が少い程此部分は II'-I' に近づくので 